\title{
Effect of Arbuscular Mycorrhizal Fungi on Germination, Nodulation and Sporulation of Lentil (Lens culinaris) at Different $\mathrm{NaCl}$ Levels
}

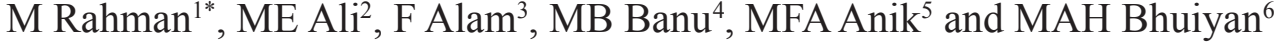 \\ ${ }^{1,4 \& 5}$ Scientific Officer, Soil Microbiology Laboratory, Bangladesh Agricultural Research Institute, Gazipur-1701, Bangladesh; ${ }^{2 \& 3}$ Senior Scientific Officer, Soil \\ Microbiology Laboratory, Bangladesh Agricultural Research Institute, Gazipur-1701, Bangladesh; ${ }^{6}$ Principal Scientific Officer, Soil Microbiology Laboratory, \\ Bangladesh Agricultural Research Institute, Gazipur-1701, Bangladesh
}

\begin{abstract}
A pot experiment was carried out in the nethouse of Soil Science Division, Bangladesh Agricultural Research Institute, Joydebpur, Gazipur during 2014-2015 through 2015-2016. The design of the experiment was factorial randomized completely block design with 4 replications. The objectives of the study were to evaluate the potential of Arbuscular mycorrhization (AM) on the germination, nodulation and sporulation of lentil treated with different concentration of $\mathrm{NaCl}$. Five $\mathrm{NaCl}$ treatments $(0,1,2,3$ and $4 \%$ ) possessed $\mathrm{NaCl}$ level as the first factor that were treated with soils before sowing of lentil seeds pivotal pulse crop in Bangladesh. The second factor consists of mycorrhizal and nonmycorrhizal treatments. Mycorrhizal plants showed better performance in terms of germination (\%), nodule number, nodule weight, spore population/100 g soil and root colonization (\%) than non-mycorrhizal plants. With increasing $\mathrm{NaCl}$ concentration, germination (\%), nodule number, nodule weight, spore population/100 $\mathrm{g}$ soil and root colonization $(\%)$ in the rhizosphere soil, decreased significantly $(\mathrm{p}<0.01)$. The highest germination $(96.25 \%$ in $2014-2015$ and $\mathbf{9 2 . 5 0 \%}$ in 2015-2016), nodule number plant ${ }^{-1}$ (28.67 in 2014-2015 and 24.34 in 2015-2016), and root colonization (30\% in $\mathbf{2 0 1 4 - 2 0 1 5}$ and $\mathbf{4 3 . 3 4 \%}$ in $\mathbf{2 0 1 5 - 2 0 1 6 )}$ was found in $\mathbf{0 \%} \mathrm{NaCl}+\mathrm{AM}$ treatment. The lowest germination\%, nodule number plant ${ }^{-1}$ and root colonization \% was found in $4 \% \mathrm{NaCl}$ treatment. Mycorrhizal inoculation increased germination on an average by $9.68 \%$ during $2014-2015$ and $11.07 \%$ during $2015-2016$, and increased root colonization on an average by $40.47 \%$ during $2014-2015$ and $25.14 \%$ during 2015-2016 over non-mycorrhizal inoculation. The study clearly indicates that mycorrhizal inoculation could reduce the harmful effects of $\mathrm{NaCl}$ toxicity to the host plants, thus increase plant survival allowing the plants growth under extreme condition. Increased overall absorption capacity, absorption surface area and longevity of absorbing roots elevated $\mathrm{NaCl}$ concentration in soils resulting detoxify the environment for plant growth.
\end{abstract}

Key words: Arbuscular mycorrhizal fungi, lentil, different $\mathrm{NaCl}$ levels

\section{Introduction}

Among the abiotic stresses salt stress is having a greater impact on farmlands worldwide. It is reported that about $7 \%$ of the total land on earth and $20 \%$ of the total arable area are affected with high salt content ${ }^{1}$. In view of another projection, $2.1 \%$ of the global dry land agriculture is affected by salinity. Over $30 \%$ of the cultivable area of Bangladesh lies in the coastal and offshore zones. Out of 2.86 million hectares of coastal and offshore lands, about 1.05 million hectares are affected by varying degrees of salinity $^{2}$. The area under salinity is increasing with time (from $0.83 \mathrm{~m}$ ha to $1.056 \mathrm{~m}$ ha in 36 years; ${ }^{2}$ ) due to rise in sea water level with increased global temperature.

Associated agricultural production losses were estimated to be close to $\$ 12$ billion per year due to soil salinization ${ }^{3}$. It has been estimated that more than $50 \%$ of the arable land would be salinized by the year $2050^{4}$. On the other hand the human race is increasing and is believed to reach 8.3 billion by 2030 . It is difficult to feed this increasing population as the productive land is decreasing day by day.
Researchers are desperate to find out suitable techniques to combat with these concerning problem ie. looking for an alternative to bring the uncultivated land under cultivation. But these techniques seems to very costly and unaffordable to underdeveloped countries, whereas microorganisms specially arbuscular mycorrhiza have the potential to reduce the sodium and chloride toxicity in crops could be a more cost effective environmental friendly option that is available in a shorter time frame. Arbuscular mycorrhizas (AM) are pervasive and they are found in $80 \%$ of vascular plant families in existence today and fungi belonging to the order glomeromycota. AM have been shown to promote plant growth ${ }^{5}$, enhance nutrient uptake such as nitrogen, phosphorus, magnesium, and micronutrients from the soil ${ }^{6}$, improve soil structure, and also able to enhance plant tolerance under different stresses such as drought and salinity ${ }^{7}$. Plants treated with AM fungi have been shown to enhance the growth and yield, and maintains the osmotic and ionic balance to a normal level so that plants will thrive well under these stress conditions ${ }^{5}$. 
Lentil (Lens culinaris) var. BARI Masur-5 belongs to the family Fabaceae and is commonly used as an important pulse crop in Bangladesh. In Bangladesh, during 2015-2016 about 154,515 ha of land is under lentil cultivation and the total production is about 158,228 metric tons $^{8}$. An ideal sustainable agricultural system is one which maintains and improves human health, benefits producers and consumers both economically and spiritually, protects the environment, conserve ecosystem and produces enough food for an increasing world population. Plant associated microorganisms ie. arbuscular mycorrhiza can play an important role in conferring resistance to alleviating salinity stresses in plants. Taking the current leads available, concerted future research is needed to have an appraisal or summing-up of the present state of land areas affected by salinity. Therefore, the overall goal of the investigation was to evaluate the potential of arbuscular mycorrhizal inoculation on the germination (\%), nodulation, and sporulation of lentil treated with different concentration of $\mathrm{NaCl}$.

\section{Materials and Methods}

\section{Seed collection and Soil preparation}

The experiment was carried out during rabi season from December, 2014 to March, 2015 and December, 2015 to March, 2016 in the net house of Soil Science Division, BARI, Joydebpur, Gazipur (230 59'38' N latitude, $90^{\circ} 24^{\prime} 89^{\prime \prime}$ E longitude and 8.4 m elevation). Seeds of lentil (BARI Masur-5) were collected from Pulse Research Centre, BARI, Gazipur. The silted (sandy clay loam) soils were collected from the bank of Turag river at Kodda, Gazipur mixed with cowdung at 5:1 ratio and was used as the potting media. Each pot ( $28 \mathrm{~cm}$ in diameter and $23 \mathrm{~cm}$ in height) was filled with approximately 8-kg soil leaving upper 3 inches of pot was vacant to facilitate watering. The $\mathrm{pH}$ of cowdung was 6.7 and the nutrient contents were: organic matter $14.1 \%, \mathrm{~N} 0.8 \%$, P $1.26 \%$, K $0.88 \%$, Ca $1.55 \%$, Mg $0.82 \%$, S $0.62 \%$, Fe $0.25 \%$ and $\mathrm{Mn} 0.112 \%$. The physical and chemical properties of the soil are presented in Table 1. The soil contained 12 AM $\left(100^{-1} \mathrm{~g}\right.$ soil) spores of indigenous mixed AM fungal species and the experiment was conducted under unsterilized soil condition.

\section{Methods of chemical analysis}

Soil $\mathrm{pH}$ was measured by a combined glass calomel electrode 9 . Organic carbon was determined by Wet Oxidation Method ${ }^{10}$. Total $\mathrm{N}$ was determined by modified Kjeldahl method ${ }^{11}$. Calcium, $\mathrm{K}$ and $\mathrm{Mg}$ were determined by $\mathrm{NH}_{4} \mathrm{OAc}$ extraction method ${ }^{12}$. Copper, $\mathrm{Fe}, \mathrm{Mn}$ and $\mathrm{Zn}$ were determined by diethylenetriaminepentaacetic acid (DTPA) extraction followed by Atomic absorption spectroscopy (AAS) reading. Boron was determined by $\mathrm{CaCl}_{2}$ extraction method. Phosphorus was determined by Modified Olsen method (Neutral + Calcareous soils) according to Olsen et al. ${ }^{13}$. Sulphur was determined by $\mathrm{CaH}_{4}\left(\mathrm{PO}_{4}\right)_{2} \cdot \mathrm{H}_{2} \mathrm{O}$ extraction followed by turbidimetric turbidity method with $\mathrm{BaCl}_{2}$.

Chemical fertilizers@23.06 kg N: 19.8 kg P: 23.09 kg K: 12.35 $\mathrm{kg} \mathrm{S:} 1.20 \mathrm{~kg} \mathrm{Zn:} 0.73 \mathrm{~kg}$ B: $0.34 \mathrm{~kg} \mathrm{Mo} \mathrm{ha}^{-1}$ was applied $^{14}$. All fertilizers were applied as basal during final land preparation.

\section{Preparation of $\mathrm{NaCl}$ solution and Mycorrhizal inoculum}

Different concentrations of $\mathrm{NaCl}$ solution was prepared according to experimental design and $250 \mathrm{~mL}$ of each percentage of $\mathrm{NaCl}$ solution were applied per pot as irrigation water in each treatment before sowing of lentil seed. The developed soil salinity was within the range of 1.04 to $3.75 \mathrm{dSm}^{-1}$.

The arbuscular mycorrhizal inoculum was prepared from the roots and rhizosphere soils of sorghum. Mycorrhizal species was originally isolated from different Agro-Ecological Zones (AEZ), using the wet sieving and decanting method. The spores were left to multiply for 6 months on sorghum plants using unsterilized soil, collected from the same site, in the net house of Soil Science Division, BARI. Plants were irrigated with tap water as needed. A mixture of infected sorghum root and soil which contained spores was used as mycorrhizal inoculum. The soil based AM fungal inoculum containing $150 \mathrm{~g}$ of rhizosphere soil (approximate $209.67 \pm 5.5$ spores $/ 100 \mathrm{~g}$ soil) and infected sorghum root fragments with a minimum infection level was inoculated to each mycorrhizal pot. Photo 1 represents different mycorrhizal spore identified in the Soil Microbiology Laboratory, Soil Science Division, BARI and used for the experiment. The mycorrhizal inoculum were first placed in each pot at $3-5 \mathrm{~cm}$ depth and was covered with a thin soil layer of $1 \mathrm{~cm}$ immediately prior to the seed sowing of lentil to facilitate fungal colonization of plant roots.

\section{Experimental design}

The experiment was designed in factorial randomized completely block design (RCBD) with 10 treatments combination and 4 replications. Twenty seeds were sown in each pot at $1 \mathrm{~cm}$ soil depth. The treatment was sustained with 11-14 vigorous seedlings in mycorrhizal and non-mycorrhizal pot and the other seedlings were removed from the pot. The 10 treatment combinations were: $\mathrm{T}_{1}: \mathrm{NaCl} 0 \%, \mathrm{~T}_{2}: \mathrm{NaCl} 0 \%+\mathrm{AM}, \mathrm{T}_{3}: \mathrm{NaCl} 1 \%, \mathrm{~T}_{4}: \mathrm{NaCl} 1 \%+$ $\mathrm{AM}, \mathrm{T}_{5}: \mathrm{NaCl} 2 \%, \mathrm{~T}_{6}: \mathrm{NaCl} 2 \%+\mathrm{AM}, \mathrm{T}_{7}: \mathrm{NaCl} 3 \%, \mathrm{~T}_{8}: \mathrm{NaCl}$ $3 \%+\mathrm{AM}, \mathrm{T}_{9}: \mathrm{NaCl} 4 \%$ and $\mathrm{T}_{10}: \mathrm{NaCl} 4 \%+\mathrm{AM}$.

\section{Determination of germination percentage}

The germination test was carried out according to ISTA rules ${ }^{15}$. For each treatment, 100 seeds were put into Petri dishes. The Petri dishes were put on a laboratory table at room temperature $\left(25 \pm 2^{\circ} \mathrm{C}\right)$. After 8 days, normal, abnormal and diseased seeds were counted. Germination of lentil seed in the laboratory table was $85 \%$. Twenty seeds were sown in each pot. After $9,12,15$, 18, 21 and 24 days germinated seeds were observed and counted. Germination percentage was calculated by the following formula:

$$
\text { Germination }(\%)=\frac{\text { Number of germinated seeds in each pot }}{\text { Total number of seeds sown in each pot }} \times 100
$$

\section{Crop harvest}

Lentils were harvested after 90 days of sowing. Nodule number, nodule weight and root infection (\%) were measured after 51 
days after sowing (DAS) ie. at the time of 50\% flowering stage of lentil.

\section{Assessment of spore population density}

Assessment of spore population was done following the Wet Sieving and Decanting Method ${ }^{16}$. Soil samples from the rhizosphere of the respective plant species were mixed thoroughly by breaking up any large lumps. Any large unwanted particles such as stone, roots, twigs etc. were removed from the soil. Then $100 \mathrm{~g}$ of mixed soil was kept in a bucket (8 litres) and filled three quarters with tap water. The soil with water was agitated by stirring vigorously by hand and washed into the bucket and left to settle for one minute. The suspension was sieved by following the wet sieving and decanting method ${ }^{16}$. Two sieves $(400 \mu \mathrm{m}$ and 100 $\mu \mathrm{m}$ mesh) were used throughout the experiment. The supernatant was poured through a $100 \mu \mathrm{m}$ sieve into the second bucked (10 litres) to avoid the loss of useful materials. After allowing the suspension to settle for one minute, the supernatant was decanted into the $400 \mu \mathrm{m}$ sieve. This time water was discarded and the material was back washed from the sieve into a beaker $(250 \mathrm{~mL})$ with a small quantity of water. The solution with spores was distributed in 4 equal size test tubes evenly and balanced up the tubes with water for equal weight. The tubes were plugged properly and then centrifuged for 4 minutes at 3,000 rpm. The supernatant was poured in test tubes and the test tubes were filled with sucrose solution and stirred vigorously with the round-ended spatula to re-suspend the precipitate. The test tubes were balanced properly to equal weight and they were plugged. Then the plugged test tubes were centrifuged for 15 seconds at 3,000 rpm. After centrifuge, the sucrose supernatant was poured through a 400 $\mu \mathrm{m}$ sieve and rapidly washed with water to remove the sucrose from AM spores by back washing the materials from the sieve into watch glass for observation.

\section{Counting of AM spores}

All the AM spores were isolated from the extract with the help of a fine forcep into a watch glass with small quantity of water. The extract, with AM spores, was observed under stereomicroscope and the number of spores was counted. Spore numbers from the three replicates per samples were averaged and the result was expressed as number per $100 \mathrm{~g}$ of dry soil basis.

\section{Assessment of root colonization infection}

The percentage of AM infection was estimated by root slide technique ${ }^{17}$. One hundred root segments were examined for each sample. The stained root pieces were mounted in acidic glycerol on slides and the cover slip was placed and slightly pressed. The roots were observed under microscope. A root segment was considered as positively infected, if it showed mycelium, vesicles and arbuscules or any other combination of these structural characteristics of AM infection. The presence or absence of infection in the root pieces was recorded and the percent infection was calculated as follows:

$$
\% \text { root colonization }=\frac{\text { Number of AM positive segments }}{\text { Total number of segments scored }} \times 100
$$

\section{Statistical analysis}

Data were statistically analyzed using Analysis of Variance (ANOVA) following CropStat package while the all pair comparisons were done by Statistix 10.

\section{Results}

\section{Effect of AM inoculation}

The effect of mycorrhizal inoculation on seed germination at 9, $12,15,18$ and 21 DAS, nodule number plant ${ }^{-1}$, nodule weight (mg plant ${ }^{-1}$ ), and spore population/100 $\mathrm{g}$ soil have been presented in Tables 2-3. On the other hand, germination $\%$ at 24 days after sowing (DAS) and root infection (\%) at 50\% flowering stage have been presented in Figures 1-2. Figure 3 represents different mycorrhizal structure found in the root cortex of lentil plants.

Mycorrhizal inoculation significantly increased germination $(40.00,55.75,68.00,74.50,77.25$ and $78.25 \%)$ at $9,12,15,18$, 21 and 24 DAS, nodule number (18.58 plant $\left.^{-1}\right)$, nodule weight (17.74 $\mathrm{mg} \mathrm{plant}^{-1}$ ), spore population/100 g soil (71.13) and root colonization (21.60\%) at 50\% flowering stage in 2014-2015 and increased germination $(59.75,74.25,80.25,83.00,85.00$ and $85.50 \%)$ at $9,12,15,18,21$ and 24 DAS, nodule number $(18.95$ plant $\left.^{-1}\right)$, nodule weight (17.15 mg plant $\left.^{-1}\right)$, spore population/100 $\mathrm{g}$ soil (103.90) and root colonization (30.63\%) at 50\% flowering stage in 2015-2016 (Tables 2-3 and Figures 1-2).

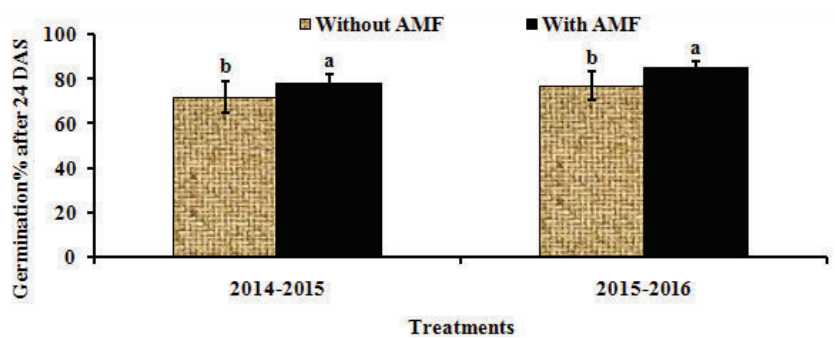

Figure 1. Effect of AMF on germination (\%) after 24 DAS of lentil

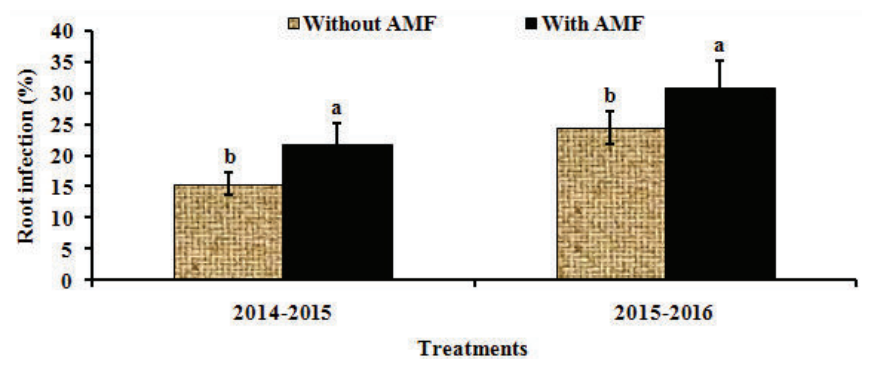

Figure 2. Effect of AMF on root colonization (\%) of lentil

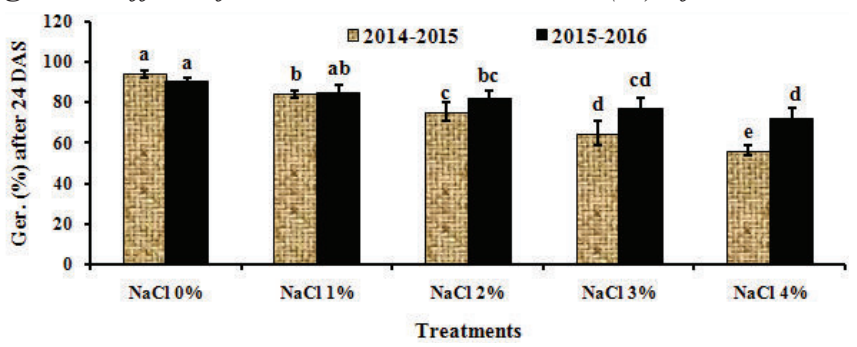

Figure 3. Effect of $\mathrm{NaCl}$ on germination (\%) after $24 \mathrm{DAS}$ of lentil 
Table 1. Initial fertility status of the soil samples

\begin{tabular}{|c|c|c|c|c|c|c|c|c|c|c|c|c|c|c|}
\hline Soil Properties & Texture & $\mathrm{pH}$ & $\mathrm{OM}(\%)$ & $\begin{array}{c}\mathrm{Ca} \\
\text { meq } 100 \mathrm{~g}^{-1}\end{array}$ & $\mathrm{Mg}$ & $\begin{array}{c}\mathrm{K} \\
\mu \mathrm{g} \mathrm{g}^{-1}\end{array}$ & Total N(\%) & $\mathrm{P}$ & $\mathrm{S}$ & $\mathrm{B}$ & $\mathrm{Cu}$ & $\mathrm{Fe}$ & $\mathrm{Mn}$ & $\mathrm{Zn}$ \\
\hline Result & $\begin{array}{c}\text { Sandy clay } \\
\text { loam }\end{array}$ & 7.6 & 0.32 & 6.6 & 2.3 & 0.09 & 0.017 & 12 & 25 & 0.10 & 1.0 & 14 & 1.3 & 0.85 \\
\hline Critical level & - & - & - & 2.0 & 0.5 & 0.12 & - & 10 & 10 & 0.20 & 0.2 & 4.0 & 1.0 & 0.60 \\
\hline
\end{tabular}

Table 2. Effect of AMF on germination (\%) of lentil

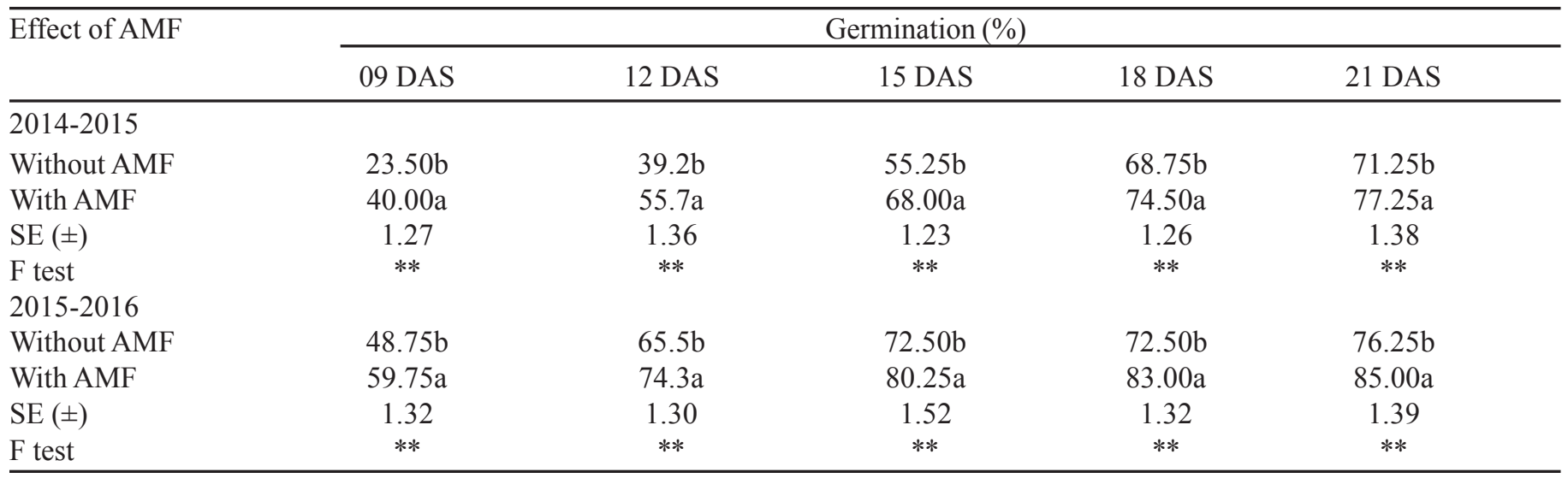

AMF: Arbuscular mycorrhizal fungi. The values represent means of 04 replicates. Different letters within each column indicate significant differences between treatments. Test CropStat and Statistix 10. **Significant Pd"0.01

Table 3. Effect of AMF on nodule number, nodule weight, and spore population of lentil

\begin{tabular}{lccc}
\hline Effect of AM & Nodule number plant $^{-1}$ & ${\text { Nodule weight }\left(\mathrm{mg} \mathrm{plant}^{-1}\right)}^{-}$ & Spore population $/ 100 \mathrm{~g}$ soil \\
\hline $2014-2015$ & & & \\
Without AMF & $0.00 \mathrm{~b}$ & $0.00 \mathrm{~b}$ & $48.63 \mathrm{~b}$ \\
With AMF & $18.58 \mathrm{a}$ & $17.74 \mathrm{a}$ & $71.13 \mathrm{a}$ \\
SE $( \pm)$ & 0.32 & 0.44 & 0.88 \\
F test & $* *$ & $* *$ & \\
$2015-2016$ & & $2.80 \mathrm{~b}$ & $95.35 \mathrm{~b}$ \\
Without AMF & $3.01 \mathrm{~b}$ & $17.15 \mathrm{a}$ & $103.90 \mathrm{a}$ \\
With AMF & $18.95 \mathrm{a}$ & 0.26 & 2.40 \\
SE $( \pm)$ & 0.26 & $* *$ & $*$ \\
F test & $* *$ & D &
\end{tabular}

AMF: Arbuscular mycorrhizal fungi. The values represent means of 04 replicates. Different letters within each column indicate significant differences between treatments. Test CropStat and Statistix 10. **Significant Pd"0.01, *significant Pd"0.05

\section{Effect of $\mathrm{NaCl}$}

Effect of different concentration of $\mathrm{NaCl}$ on lentil has been presented in Tables 4-5 and Figures 4-5. Significant differences were found in case of germination (\%) at $9,12,15,18,21$ and 24 DAS, nodule number plant ${ }^{-1}$, nodule weight $\left(\mathrm{mg} \mathrm{plant}^{-1}\right)$, spore population/100 $\mathrm{g}$ soil and root infection (\%).

The highest germination $(69.38,81.88,88.75,93.75,94.38$ and $94.38 \%$ ) at $9,12,15,18,21$ and 24 DAS, respectively, nodule number (14.33 plant $\left.\mathrm{t}^{-1}\right)$, nodule weight $\left(13.05 \mathrm{mg} \mathrm{plant}^{-1}\right)$, spore population/100 g soil (79.58) and root colonization (25.00\%) in 2014-2015, and highest germination $(78.13,86.88,90.00,89.38$, 90.63 and $90.63 \%$ ) at $9,12,15,18,21$ and 24 DAS, respectively, nodule number (13.96 plant $\left.{ }^{-1}\right)$, nodule weight (12.75 mg plant ${ }^{-}$ ${ }^{1}$ ), spore population/100 g soil (123.50) and root colonization
(38.34\%) in 2015-2016 were observed in $0 \% \mathrm{NaCl}$ treatment (Tables 4-5 and Figures 4-5). The lowest germination (11.25, $20.00,35.63,51.25,55.00$ and $56.25 \%$ ) at $9,12,15,18,21$ and 24 DAS, respectively, nodule number $\left(05.35\right.$ plant $\left.^{-1}\right)$, nodule weight (05.21 mg plant ${ }^{-1}$ ), spore population/100 g soil (40.83) and root colonization $(12.50 \%)$ in 2014-2015, and lowest germination $(31.25,50.00,60.63,65.63,70.63$ and $72.50 \%)$ at $9,12,15,18,21$ and 24 DAS, respectively, nodule number $(09.00$ plant $\left.^{-1}\right)$, nodule weight $\left(08.00 \mathrm{mg} \mathrm{plant}^{-1}\right)$, spore population $/ 100$ $\mathrm{g}$ soil (78.00) and root colonization (15.00\%) in 2015-2016 were observed in $4 \% \mathrm{NaCl}$ treatment (Tables 4-5 and Figures 4-5).

The highest germination (\%) at 9, 12, 15, 18, 21 and 24 DAS, nodule number plant ${ }^{-1}$, nodule weight $\left(\mathrm{mg} \mathrm{plant}^{-1}\right)$, spore population/100 g soil and root infection (\%) in 2014-2015 were 
found in $0 \% \mathrm{NaCl}$ level which was significantly higher over all other $\mathrm{NaCl}$ levels while the highest germination (\%) at 9, 12, 15, 18,21 and 24 DAS in 2015-2016 were found in $0 \% \mathrm{NaCl}$ level which was significantly higher over $2 \% \mathrm{NaCl}, 3 \% \mathrm{NaCl}$ and $4 \%$ $\mathrm{NaCl}$ level but identical to $1 \% \mathrm{NaCl}$ level. The highest nodule number plant ${ }^{-1}$, nodule weight (mg plant ${ }^{-1}$ ), spore population/100 $\mathrm{g}$ soil and root infection (\%) in 2015-2016 were found in $0 \% \mathrm{NaCl}$ level which was significantly higher over all other $\mathrm{NaCl}$ levels.

\section{Interaction effects of mycorrhizal inoculation and $\mathrm{NaCl}$}

Interaction effects of mycorrhizal inoculation and $\mathrm{NaCl}$ on lentil have been presented in Table 6 and Figures 6-8. Interaction effects

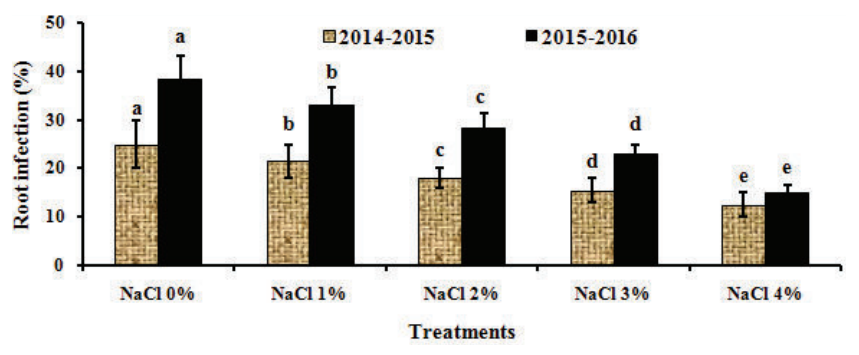

Figure 4. Effect of $\mathrm{NaCl}$ on root colonization (\%) of lentil

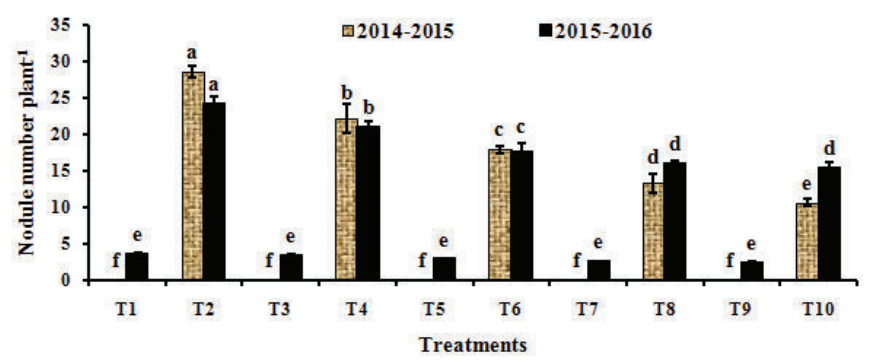

Figure 5. Interaction effects of arbuscular mycorrhizal fungi and $\mathrm{NaCl}$ on nodule number plant ${ }^{-1}$ of lentil. $\mathrm{T}_{1}: \mathrm{NaCl} 0 \%, \mathrm{~T}_{2}$ : $\mathrm{NaCl} 0 \%+\mathrm{AM}, \mathrm{T}_{3}: \mathrm{NaCl} 1 \%, \mathrm{~T}_{4}: \mathrm{NaCl} 1 \%+\mathrm{AM}, \mathrm{T}_{5}: \mathrm{NaCl}$ $2 \%, T_{6}: \mathrm{NaCl} 2 \%+\mathrm{AM}, \mathrm{T}_{7}: \mathrm{NaCl} 3 \%, \mathrm{~T}_{8}: \mathrm{NaCl} 3 \%+\mathrm{AM}, \mathrm{T}_{9}$ : $\mathrm{NaCl} 4 \%$ and $\mathrm{T}_{10}: \mathrm{NaCl} 4 \%+\mathrm{AM}$.

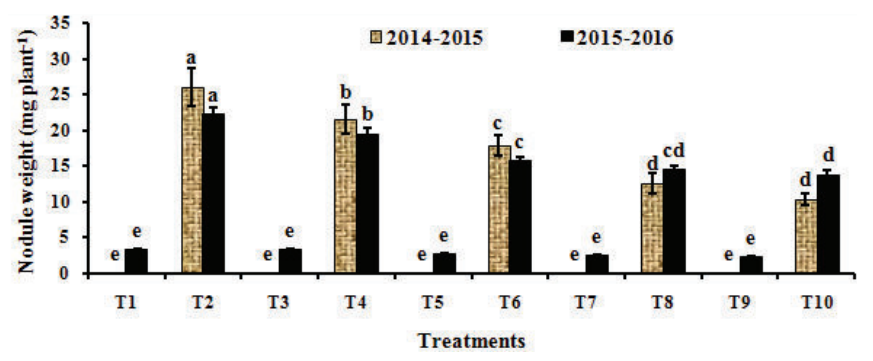

Figure 6. Interaction effects of arbuscular mycorrhizal fungi and $\mathrm{NaCl}$ on nodule weight ( $\mathrm{mg}_{\text {plant }}{ }^{-1}$ ) of lentil. $\mathrm{T}_{1}: \mathrm{NaCl} 0 \%$, $\mathrm{T}_{2}: \mathrm{NaCl} 0 \%+\mathrm{AM}, \mathrm{T}_{3}: \mathrm{NaCl} 1 \%, \mathrm{~T}_{4}: \mathrm{NaCl} 1 \%+\mathrm{AM}, \mathrm{T}_{5}: \mathrm{NaCl}$ $2 \%, \mathrm{~T}_{6}: \mathrm{NaCl} 2 \%+\mathrm{AM}, \mathrm{T}_{7}: \mathrm{NaCl} 3 \%, \mathrm{~T}_{8}: \mathrm{NaCl} 3 \%+\mathrm{AM}, \mathrm{T}_{9}$ : $\mathrm{NaCl} 4 \%$ and $\mathrm{T}_{10}: \mathrm{NaCl} 4 \%+\mathrm{AM}$. of mycorrhizal inoculation and $\mathrm{NaCl}$ on germination (\%) at 12 , $15,18,21$ and 24 days after sowing (DAS), spore population/100 $\mathrm{g}$ soil and root infection (\%) were not significant except germination (\%) at 09 and 12 DAS; nodule number plant ${ }^{-1}$ and nodule weight $\left(\mathrm{mg}\right.$ plant $\left.^{-1}\right)$. This indicates that mycorrhizal inoculation was equally effective to all the $\mathrm{NaCl}$ levels in all the parameters except germination (\%) at 09 and $12 \mathrm{DAS}$, nodule number plant ${ }^{-1}$ and nodule weight (mg plant $\left.{ }^{-1}\right)$. However, germination (\%) at 09 and 12 DAS was considered as a very early growth stage for lentil. Un-inoculated treatments produced less number of nodule compared to inoculated treatments subsequently given less nodule weight compared to inoculated treatments.

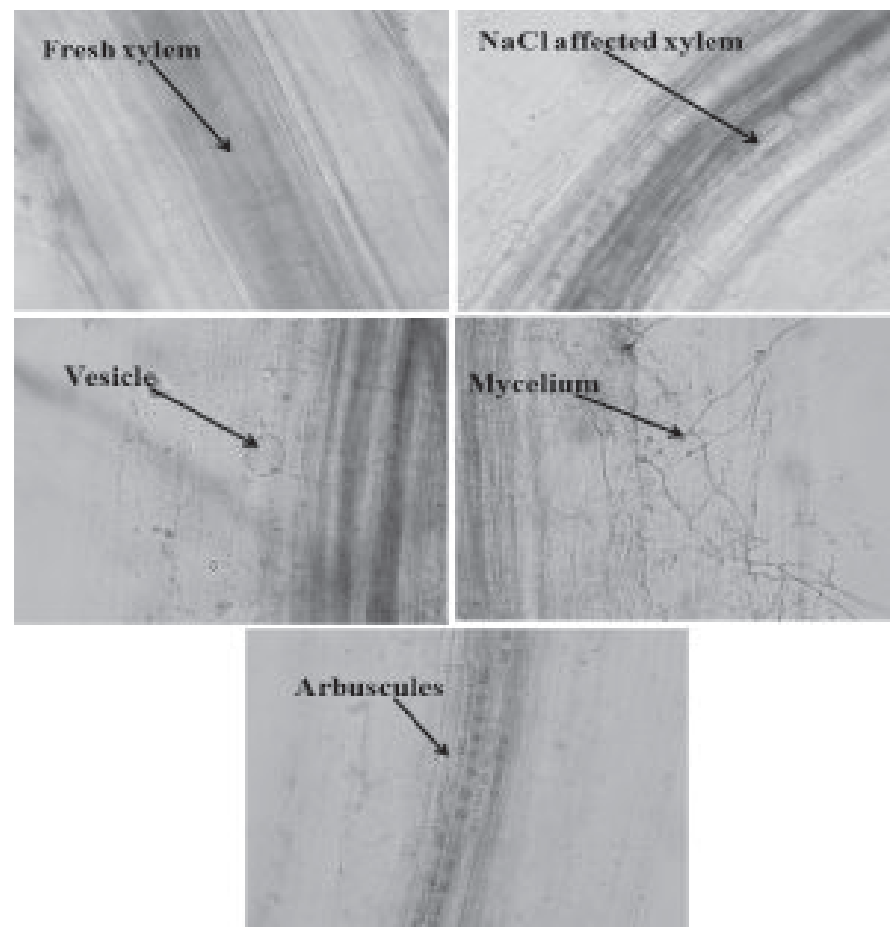

Figure 7. Different mycorrhizal structure found in the root cortex of lentil (Lens culinaris).

Table 4. Effect of $\mathrm{NaCl}$ on germination (\%) of lentil

\begin{tabular}{lccccc}
\hline Effect of & \multicolumn{5}{c}{ Germination (\%) } \\
$\mathrm{NaCl}$ & 09 DAS & $12 \mathrm{DAS}$ & $15 \mathrm{DAS}$ & $18 \mathrm{DAS}$ & $21 \mathrm{DAS}$ \\
\hline $2014-2015$ & & & & \\
$\mathrm{NaCl} \%$ & $69.38 \mathrm{a}$ & $81.88 \mathrm{a}$ & $88.75 \mathrm{a}$ & $93.75 \mathrm{a}$ & $94.38 \mathrm{a}$ \\
$\mathrm{NaCl} \mathrm{1 \%}$ & $42.50 \mathrm{~b}$ & $64.38 \mathrm{~b}$ & $80.63 \mathrm{~b}$ & $82.50 \mathrm{~b}$ & $83.75 \mathrm{~b}$ \\
$\mathrm{NaCl} \mathrm{2 \%}$ & $23.13 \mathrm{c}$ & $45.00 \mathrm{c}$ & $60.00 \mathrm{c}$ & $70.63 \mathrm{c}$ & $74.38 \mathrm{c}$ \\
$\mathrm{NaCl} \mathrm{3 \%}$ & $12.50 \mathrm{~d}$ & $26.25 \mathrm{~d}$ & $43.13 \mathrm{~d}$ & $60.00 \mathrm{~d}$ & $63.75 \mathrm{~d}$ \\
$\mathrm{NaCl} \mathrm{4 \%}$ & $11.25 \mathrm{~d}$ & $20.00 \mathrm{e}$ & $35.63 \mathrm{e}$ & $51.25 \mathrm{e}$ & $55.00 \mathrm{e}$ \\
$\mathrm{SE}( \pm)$ & 2.01 & 2.14 & 1.94 & 1.99 & 2.19 \\
$\mathrm{~F} \mathrm{test}$ & $* *$ & $* *$ & $* *$ & $* *$ & $* *$ \\
$2015-2016$ & & & & & \\
$\mathrm{NaCl} \mathrm{0 \%}$ & $78.13 \mathrm{a}$ & $86.88 \mathrm{a}$ & $90.00 \mathrm{a}$ & $89.38 \mathrm{a}$ & $90.63 \mathrm{a}$ \\
$\mathrm{NaCl} \mathrm{1 \%}$ & $76.25 \mathrm{a}$ & $84.38 \mathrm{a}$ & $85.00 \mathrm{a}$ & $83.75 \mathrm{a}$ & $85.00 \mathrm{ab}$ \\
$\mathrm{NaCl} \mathrm{2 \%}$ & $49.38 \mathrm{~b}$ & $66.88 \mathrm{~b}$ & $76.25 \mathrm{~b}$ & $77.50 \mathrm{~b}$ & $81.88 \mathrm{~b}$ \\
$\mathrm{NaCl} \mathrm{3 \%}$ & $36.25 \mathrm{c}$ & $61.25 \mathrm{~b}$ & $70.00 \mathrm{~b}$ & $72.50 \mathrm{~b}$ & $75.00 \mathrm{c}$ \\
$\mathrm{NaCl} \mathrm{4 \%}$ & $31.25 \mathrm{c}$ & $50.00 \mathrm{c}$ & $60.63 \mathrm{c}$ & $65.63 \mathrm{c}$ & $70.63 \mathrm{c}$ \\
$\mathrm{SE}( \pm)$ & 2.09 & 2.07 & 2.41 & 2.08 & 2.20 \\
$\mathrm{~F} \mathrm{test}$ & $* *$ & $* *$ & $* *$ & $* *$ & $* *$ \\
\hline
\end{tabular}

The values represent means of 04 replicates. Different letters within each column indicate significant differences between treatments. Test CropStat and Statistix 10. **Significant Pd"0.01 
Table 5. Effect of $\mathrm{NaCl}$ on nodule number, nodule weight and spore population of lentil

\begin{tabular}{|c|c|c|c|}
\hline Effect of $\mathrm{NaCl}$ & Nodule number plant ${ }^{-1}$ & Nodule weight (mg plant $\left.{ }^{-1}\right)$ & Spore population/100 g soil \\
\hline \multicolumn{4}{|l|}{$2014-2015$} \\
\hline $\mathrm{NaCl} 0 \%$ & $14.33 \mathrm{a}$ & $13.05 \mathrm{a}$ & $79.58 \mathrm{a}$ \\
\hline $\mathrm{NaCl} 2 \%$ & $9.00 \mathrm{c}$ & $9.00 \mathrm{~b}$ & $60.67 \mathrm{c}$ \\
\hline $\mathrm{NaCl} 3 \%$ & $6.68 \mathrm{~d}$ & $6.34 \mathrm{c}$ & $49.92 d$ \\
\hline $\mathrm{NaCl} 4 \%$ & $5.35 \mathrm{e}$ & $5.21 \mathrm{c}$ & $40.83 \mathrm{e}$ \\
\hline \multicolumn{4}{|l|}{ 2015-2016 } \\
\hline $\mathrm{NaCl} 0 \%$ & $13.96 \mathrm{a}$ & $12.75 \mathrm{a}$ & $122.25 \mathrm{a}$ \\
\hline $\mathrm{NaCl} 1 \%$ & $12.29 b$ & $11.38 \mathrm{~b}$ & $109.50 b$ \\
\hline $\mathrm{NaCl} 2 \%$ & $10.33 \mathrm{c}$ & $9.25 \mathrm{c}$ & $98.63 \mathrm{bc}$ \\
\hline $\mathrm{NaCl} 3 \%$ & $9.31 \mathrm{~cd}$ & $8.50 \mathrm{~cd}$ & $89.75 c$ \\
\hline
\end{tabular}

Table 6. Interaction effects of $\mathrm{AMF}$ and $\mathrm{NaCl}$ on germination (\%), spore population and root colonization of lentil

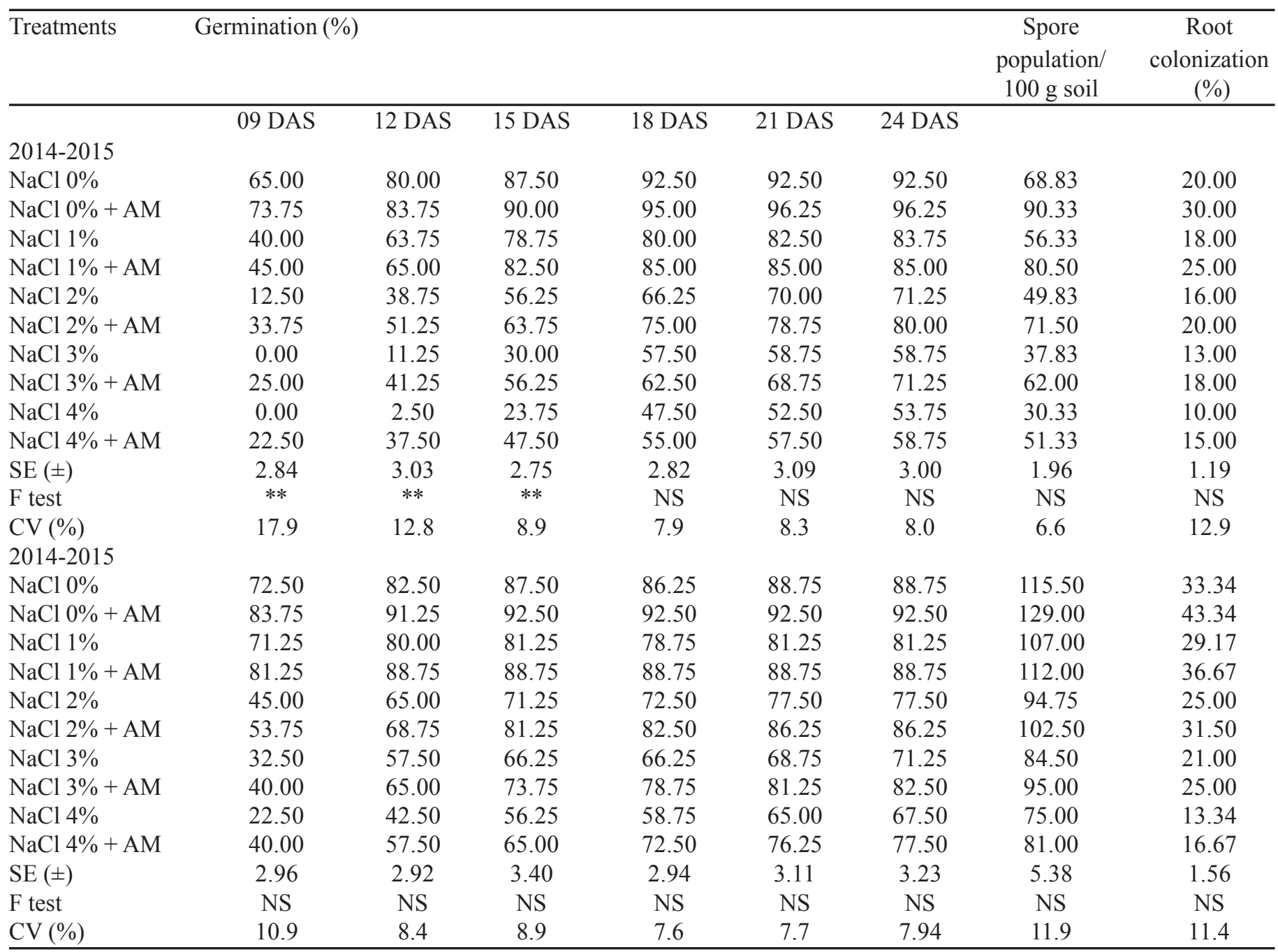

AM: Arbuscular mycorrhizal fungi. The values represent means of 04 replicates. Different letters within each column indicate significant differences between treatments. Test CropStat and Statistix 10. **Significant Pd"0.01, NS non significant. 


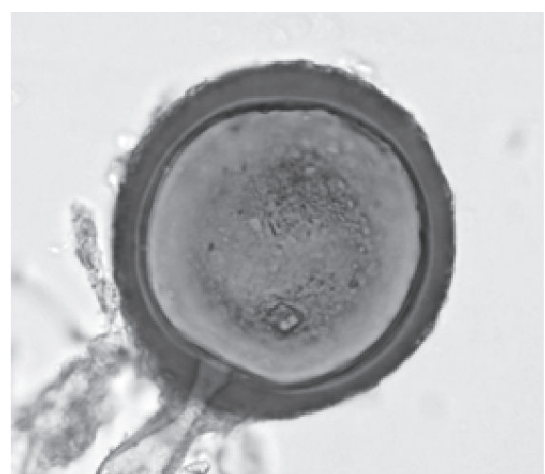

Glomus fusianum

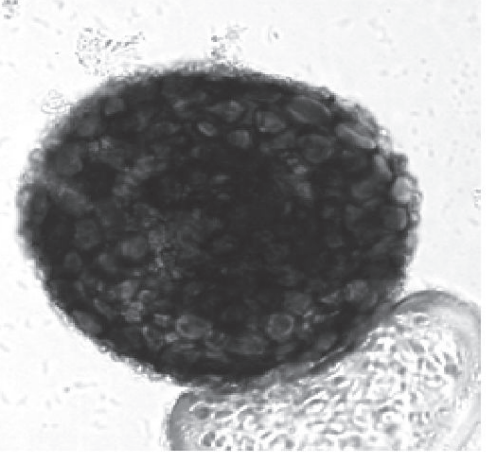

Acaulospora foveata

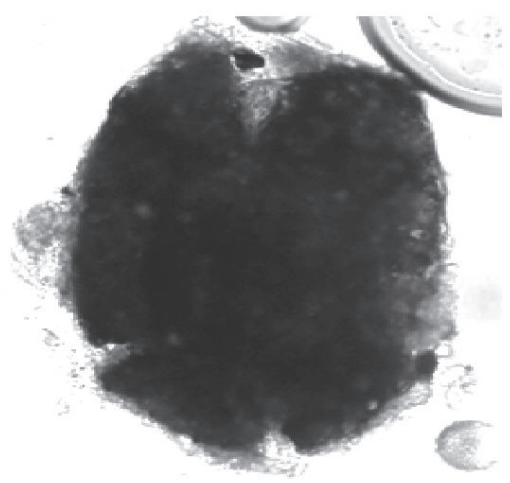

Gigaspora rosea

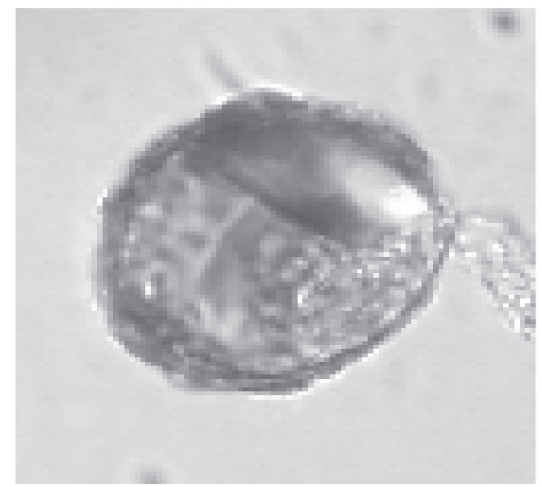

Not identified
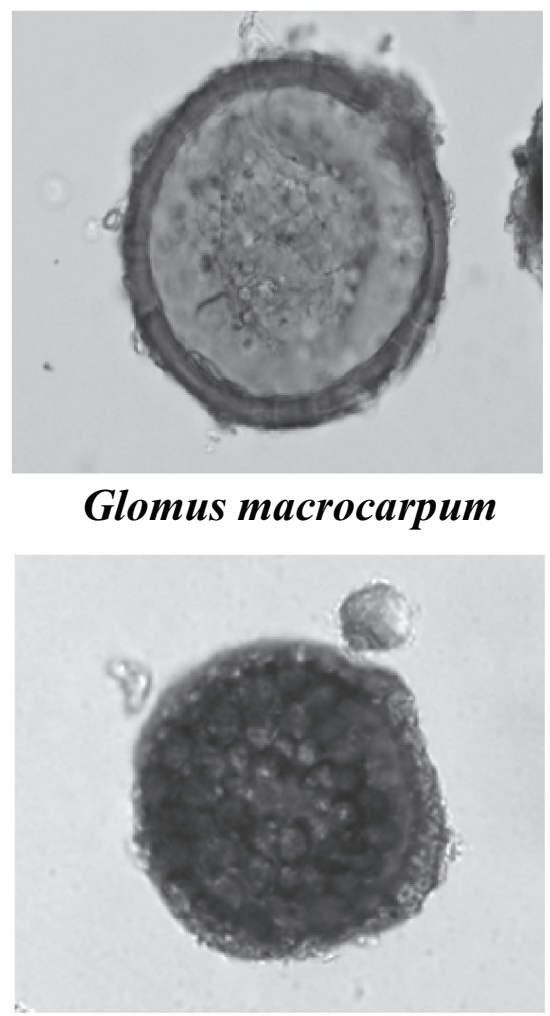

Acaulospora denticulate

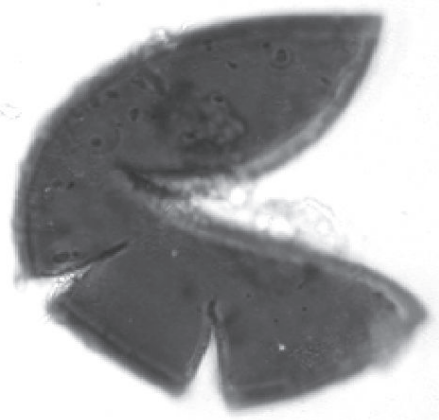

Gigaspora spp.

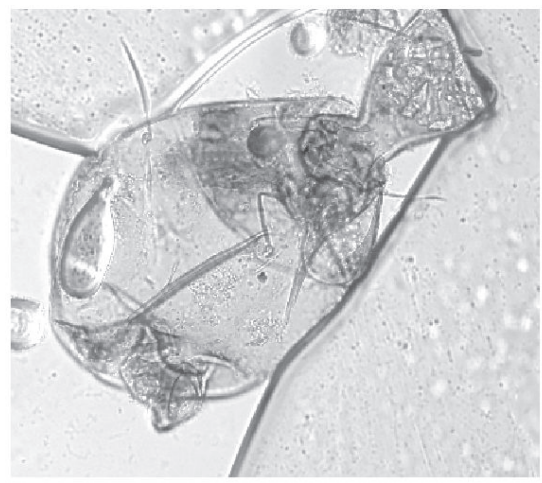

Not identified

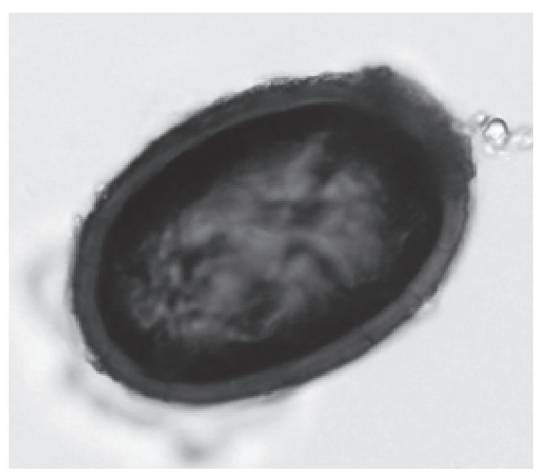

Glomus warcuppi

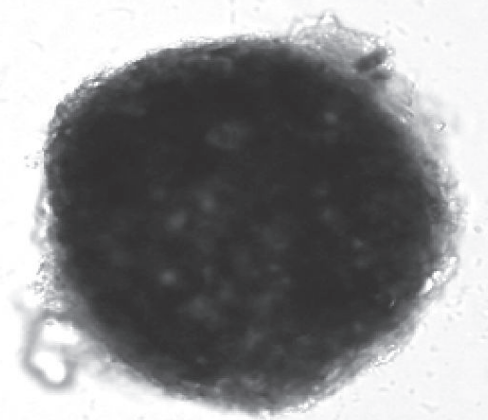

Gigaspora albida

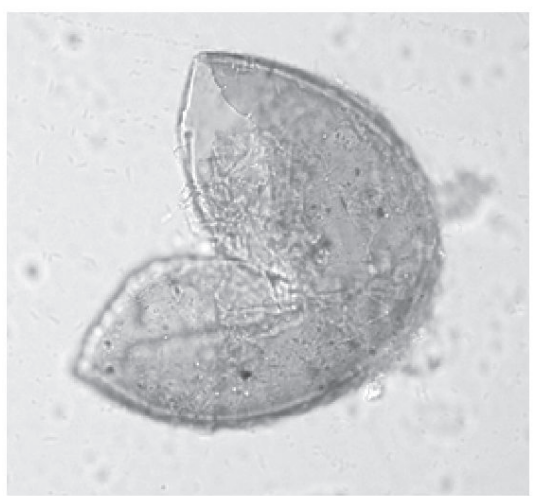

Gigaspora spp.

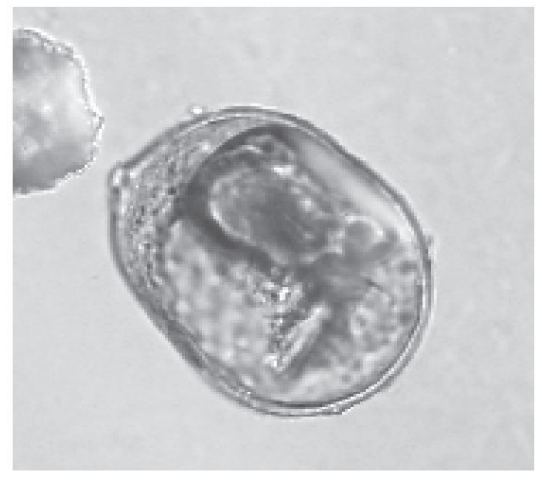

Not identified

Figure 8. Different mycorrhizal spore identified in the Soil Microbiology Laboratory, Soil Science Division, BARI and used for the experiment 


\section{Discussion}

Mycorrhizal treatments significantly increased germination (\%) because AMF entangle soil particles within the hyphae, tapping carbon resourses, reduce damage caused by pathogen, influence soil microbial activity, increased mobilization and transfer of nutrients and increased availability of added or fixed phosphorus. Eight varieties were used for evaluation of salt tolerance on the basis of seed germination; seed germination was decreased significantly in all cultivars when levels of salinity increased 3 to $14 \mathrm{dSm}^{-118}$.

Nodule number and nodule weight significantly increased in the mycorrhizal treatments because AMF influences soil microbial activity or increase the population of soil microorganisms. Our results of decreasing root colonization corroborates with the findings of Juniper and Abbott ${ }^{19}$, they also reported that salt stress can affect AM fungi by slowing down root colonization, spore germination and hyphal growth. The reason behind the increase of colonization at low concentrations of salt and decrease at high concentrations of salt may be AM fungal species have varying tolerance to salinity. Johnson-Green et al. ${ }^{20}$ reported that arbuscular mycorrhizal fungi could resist $50 \mathrm{mg}$ total salt $\mathrm{ml}^{-1}$ soil water. Root coloization by $\mathrm{AMF}$ is reduced by $\mathrm{NaCl}$ and is reported by Giri et al. ${ }^{21}$ in Acacia nilotica, Sheng et al. ${ }^{22}$ in Zea mays. It indicates that AMF is suppressed by $\mathrm{NaCl}$ stress ${ }^{22}$. Application of $\mathrm{NaCl}$ significantly reduced growth responses, flower parameters, mineral contents, and levels of mycorrhizal colonization of mycorrhizal and non-mycorrhizal kalanchoe plants comparing to control plants, mainly at high concentrations $^{23}$. From the reports it was concluded that the hyphal growth was sensitive to increasing concentration of $\mathrm{NaCl}$. AM fungi colonization was found to be effective in several crop plants such as sunflower, maize, soybean, potato, and wheat ${ }^{24}$. Lin et al. ${ }^{25}$ reported phosphorus in double concentrations in the shoots and roots of mycorrhizal Trifolium repens, indicating that AM colonization provides higher percentage of phosphorus concentration than non-mycorrhizal plants ${ }^{26}$.

\section{Conclusion}

Results of the experiment revealed that mycorrhizal plants showed better performance in terms of germination (\%), nodule number plant $^{-1}$, nodule weight $\left(\mathrm{mg} \mathrm{plant}^{-1}\right)$, spore population/100 g soil and root infection (\%) than non-mycorrhizal plants i.e. inoculation of mycorrhiza in $\mathrm{NaCl}$ contaminated soil have improved the growing conditions of plants, significantly. With the increase of $\mathrm{NaCl}$ concentration, germination (\%), nodule number plant ${ }^{-1}$, nodule weight (mg plant $\left.{ }^{-1}\right)$, spore population/100 g soil and root infection (\%) decreased significantly. The highest germination (96.25\% in 2014-2015 and $92.50 \%$ in 2015-2016), nodule number plant ${ }^{-1}$ (28.67 in 2014-2015 and 24.34 in 2015-2016), and root colonization (30\% in 2014-2015 and 43.34\% in 20152016) was found in $0 \% \mathrm{NaCl}+\mathrm{AM}$ treatment. The lowest germination $\%$, nodule number plant $^{-1}$ and root colonization $\%$ was found in $4 \% \mathrm{NaCl}$ treatment. Mycorrhizal inoculation increased germination on an average by $9.68 \%$ during $2014-2015$ and $11.07 \%$ during $2015-2016$, and increased root colonization on an average by $40.47 \%$ during $2014-2015$ and $25.14 \%$ during 2015-2016 over non-mycorrhizal inoculation. The study clearly indicates that mycorrhizal inoculation could reduce the harmful effects of $\mathrm{NaCl}$ toxicity to the host plants, thus increase plant survival allowing the plants growth under extreme condition.

\section{References}

1. Mali BS, Thengal SS and Pate PN. 2012. Physico-chemical characteristics of salt affected soil from Barhanpur. Indian J. Biol. Res. 3: 4091-4093.

2. SRDI 2010. Saline soils of Bangladesh. SRMAF Project, Ministry of Agriculture, Dhaka, Bangladesh. pp 1-60.

3. Pitman M and Läuchli A. 2002. Global impact of salinity and agricultural ecosystems. In: Läuchli A and Lüttge U. (Ed.) Salinity: environmentplants-molecules. Springer, Netherlands. pp 3-20.

4. Jamil A, Riaz S, Ashraf M and Foolad MR. 2011. Gene expression profiling of plants under salt stress. Crit. Rev. Plant Sci. 30(5): 435-458.

5. Hameed A, Egamberdieva D, Abd_Allah EF, Hashem A, Kumar A and Ahmad P. 2014. Salinity stress and arbuscular mycorrhizal symbiosis in plants. In: (Ed.): Miransari M. Use of Microbes for the Alleviation of Soil Stresses (Springer New York). 1: 139-159.

6. Evelin H, Giri B and Kapoor R. 2012. Contribution of Glomus intraradices inoculation to nutrient acquisition and mitigation of ionic imbalance in NaCl-stressed Trigonella foenum-graecum. Mycorrhiza. 22: 203-217.

7. Wu QS, Zou YN and Abd_Allah EF. 2014. Mycorrhizal Association and ROS in Plants. In: (Ed.): Ahmad P. Oxidative Damage to Plants. Elsevier Inc. pp 453-475.

8. BBS. 2016. Yearbook of Agricultural Statistics (28 $8^{\text {th }}$ series). Bangladesh Bureau of Statistics. Statistics and Information Division. Ministry of Planning, Government of the People's Republic of Bangladesh. pp 101.

9. Jackson ML. 1958. Soil Chemical Analysis. Constable and Co. Ltd., London.

10. Walkey A and Black IA. 1934. An examination of degtiareff method for determining soils organic matter and a proposed modification of the chromic acid titration method. Soil Sci. 37: 29-38.

11. Jackson ML. 1962. Soil Chemical analysis. Constable and Co. Ltd. London.

12. Black CA. 1965. Methods of Soil Analysis. Part I and II. American Soc. of Argon. Inc. Pub. Madison, Wisconsin, USA.

13. Olsen SR, Cole CV, Watanabe FS and Dean LA. 1954. Estimation of available phosphorus in soils by extraction with sodium bicarbonate. U.S. Dept. Agric. Circ. pp 939.

14. BARC (Bangladesh Agricultural Research Council). 2012. Fertilizer Recommendation Guide. Bangladesh Agricultural Research Council, Farmgate, New Airport Road, Dhaka-1215. pp 101.

15. ISTA (International Seed Testing Association). 1976. International Rules for Seed Testing. Seed Sci. Tech. 4: 3-49.

16. Gerdemann JW and Nicolson TH. 1963. Species of mycorrhizal endogone species extracted from soil by wet sieving and decanting method. Trans. Brit. Mycol. Soc. 46: 235-246.

17. Read DJ, Koucheki HK and Hodgaon J. 1976. Vesicular arbuscular mycorrhiza in natural vegetation systems. New Phytol. 77: 641-653.

18. Kumar A, Agarwal S and Singh A. 2014. Salinity effects the germination and seedling growth in some cultivars of oat (Avena sativa L.). Indian J. Advances in Plant Res. (IJAPR). 1(2): 1-10.

19. Juniper S and Abbott LK. 2006. Soil salinity delays germination and limits growth of hyphae from propagules of arbuscular mycorrhizal fungi. Mycorrhiza. 16: 371-379. 
20. Johnson-Green P, Kenkel NC and Booth T. 2001. Soil salinity and arbuscular mycorrhizal colonization of Puccinellia nuttalliana. Mycological Res. 105: 1094-1110.

21. Giri B, Kapoor R and Mukerji KG. 2007. Improved tolerance of Acacia nilotica to salt stress by arbuscular mycorrhiza, Glomus fasciculatum, may be partly related to elevated $\mathrm{K}+/ \mathrm{Na}+$ ratios in root and shoot tissues. Microbial. Ecol. 54: 753-760.

22. Sheng M, Tang M, Chan H, Yang B, Zhang F and Huang Y. 2008. Influence of arbuscular mycorrhizae on photosynthesis and water status of maize plants under salt stress. Mycorrhiza. 18: 287-296.

23. Abdul-Wasea AA, Abdel-Fattah GM, Elhindi KM and Abdel-Salam EM. 2014. The impact of arbuscular mychorrhizal fungi in improving growth, flower yield and tolerance of kalanchoe (Kalanchoe blossfeldiana Poelin) plants grown in NaCl-stress conditions. J. Food Agric. Environ. 12(1): 105-112.

24. Dahlgren RA, Saigusa M and Ugolini FC. 2004. The nature properties and management of volcanic soils. Adv. Agron. 82: 393-472.

25. Lin X, George E and Marschner H. 1991. Extension of the phosphorus depletion zone in VA mycorrhizal white clover in a calcareous soil. Plant Soil. 136: 41-48.

26. Ortas I, Sari N, Akpinar C and Yetisir H. 2011. Screening mycorrhiza species for plant growth, $\mathrm{P}$ and $\mathrm{Zn}$ uptake in pepper seedling grown under greenhouse conditions. Sci. Hort. 128: 92-98. 